Article

\title{
Potent Broad-Spectrum Antibacterial Activity of Amphiphilic Peptides against Multidrug-Resistant Bacteria
}

\author{
Yuan Liu ${ }^{1,2,3,4,+}{ }^{D}$, Jingru Shi ${ }^{1,+}$, Ziwen Tong ${ }^{1}$, Yuqian Jia ${ }^{1}$, Kangni Yang ${ }^{1}$ and \\ Zhiqiang Wang 1,3,4,* \\ 1 College of Veterinary Medicine, Yangzhou University, Yangzhou 225009, China; \\ liuyuan2018@yzu.edu.cn (Y.L.); Shijr2019@163.com (J.S.); tongzw2019@163.com (Z.T.); \\ jiayq2019@163.com (Y.J.); yangkn2019@163.com (K.Y.) \\ 2 Institute of Comparative Medicine, Yangzhou University, Yangzhou 225009, China \\ 3 Jiangsu Co-Innovation Center for Prevention and Control of Important Animal Infectious Diseases and \\ Zoonoses, Yangzhou University, Yangzhou 225009, China \\ 4 Joint International Research Laboratory of Agriculture and Agri-Product Safety, \\ The Ministry of Education of China, Yangzhou University, Yangzhou 225009, China \\ * Correspondence: zqwang@yzu.edu.cn \\ + These authors contributed equally to this work.
}

Received: 16 August 2020; Accepted: 9 September 2020; Published: 11 September 2020

check for updates

\begin{abstract}
The emergence and prevalence of multidrug-resistant (MDR) bacteria particularly Gram-negative bacteria presents a global crisis for human health. Colistin and tigecycline were recognized as the last resort of defenses against MDR Gram-negative pathogens. However, the emergence and prevalence of $\mathrm{MCR}$ or Tet(X)-mediated acquired drug resistance drastically impaired their clinical efficacy. It has been suggested that antimicrobial peptides might act a crucial role in combating antibiotic resistant bacteria owing to their multiple modes of action and characteristics that are not prone to developing drug resistance. Herein, we report a safe and stable tryptophan-rich amphiphilic peptide termed WRK-12 with broad-spectrum antibacterial activity against various MDR bacteria, including MRSA, colistin and tigecycline-resistant Escherichia coli. Mechanistical studies showed that WRK-12 killed resistant E. coli through permeabilizing the bacterial membrane, dissipating membrane potential and triggering the production of reactive oxygen species (ROS). Meanwhile, WRK-12 significantly inhibited the formation of an E. coli biofilm in a dose-dependent manner. These findings revealed that amphiphilic peptide WRK-12 is a promising drug candidate in the fight against MDR bacteria.
\end{abstract}

Keywords: antimicrobial peptides; antibiotic resistance; colistin; tigecycline; Gram-negative bacteria

\section{Introduction}

Pathogenic bacteria particularly Gram-negative pathogens such as Escherichia coli, Klebsiella pneumoniae, Pseudomonas aeruginosa and Acinetobacter baumannii have been a major cause of systemic infections in clinics [1,2]. More alarmingly, these pathogens have developed multiple acquired resistance against current antimicrobial treatments [3-5]. For example, the acquisition of metallo- $\beta$-lactamases (MBLs) such as NDM-1 resulted in the emergence of carbapenem-resistant Gram-negative pathogens [6]. Mobile colistin resistance gene $m c r-1$ and its variants [7,8] protect Enterobacteriaceae from colistin killing, an important cationic antibiotic that is recognized as one of last-resort options against multidrug-resistant (MDR) Gram-negative bacteria [9]. In addition, recent study revealed that tet $(\mathrm{X} 3 / \mathrm{X} 4)$ genes located on plasmid confer high level tigecycline resistance in 
E. coli and A. baumannii $[10,11]$. To date, these drug-resistant pathogens have been classified as a critical priority for global human health by the WHO (World Health Organization). Notably, the co-harboring of $b l a_{\mathrm{NDM}}, m c r-1$ and/or tet $(\mathrm{X})$ genes in clinical isolates makes it more difficult to treat MDR pathogens' associated infectious diseases. There is an urgent and unmet need to identify new antimicrobial agents to address this resistance crisis.

Antimicrobial peptides (AMPs), also named host defense peptides, are originated from various organisms and are important immune modulation molecules that protect the host from the invading pathogens [12]. Compared with conventional antimicrobial agents, AMPs possess distinct modes of action and are less likely to achieve resistance $[13,14]$. However, the high cost of peptides, the lability to proteases, less bioavailable and nonspecific toxicity still hinder these AMPs in clinical practice. A more rational design of AMPs contributes to improving their stability and antibacterial activity. One strategy is to introduce more aromatic amino acids such as tryptophan into peptides. The interaction of highly hydrophobic indole ring of tryptophan with the headgroup region of the membrane enable the tryptophan-rich peptides to greatly penetrate the cytoplasmic membrane $[15,16]$. In addition, pairwise Trp-Trp interactions lead to a distinctive cross-strand contact and stable tertiary structure [17]. A typical example is a synthetic hexapeptide MP196 (RWRWRW- $\mathrm{NH}_{2}$ ), which is effective against Gram-positive bacteria but displays relatively weak antibacterial activity against Gram-negative bacteria [18]. However, the high hemolysis to RBCs and low in vivo stability strongly limit its utilization in the clinical setting [19]. Nevertheless, MP196 provides a promising parent structure for the next structural optimization or derivatization, and has yielded several AMPs with better pharmacological properties, stability and/or improved activities [20,21].

To identify novel leads against MDR bacteria, we collected and designed a collection of tryptophan-rich amphiphilic antibacterial peptides based on the structure of MP196 and assessed their antibacterial activity against a panel of MDR bacteria. As a consequence, we found a stable and potent dodecapeptide termed WRK-12 that could effectively kill various MDR bacteria, including notorious methicillin-resistant Staphylococcus aureus (MRSA), vancomycin resistant Enterococcus (VRE), carbapenem-resistant Enterobacteriaceae (CRE) and mor-1-positive E. coli (MCRPEC) and tet(X4)-positive bacteria. Mechanistical experiments indicated that WRK-12 permeabilizes the bacterial membrane and triggers the production of reactive oxygen species (ROS). Consistently, the addition of ROS scavenger NAC ( $\mathrm{N}$-acetylcysteine) abolishes its antibacterial activity. Moreover, WRK-12 dramatically prevented the formation of biofilm, thus providing a lead compound in the battle against MDR bacteria.

\section{Materials and Methods}

\subsection{Peptide Synthesis and Validation}

All peptides used in this study were synthesized by GL Biochem (Shanghai, China) using a solid phase peptide synthesis (SPPS) method [22], and their accurate molecular weights were determined by matrix-assisted laser desorption/ionization time-of-flight mass spectrometry (MALDI-TOF MS). The peptide purity (>95\%) and retention time were determined by reversed-phase high-performance liquid chromatography (HPLC).

The charge and hydrophobic moment of all peptides were calculated using the HeliQuest analysis website (http://heliquest.ipmc.cnrs.fr/cgi-bin/ComputParamsV2.py). The three-dimensional structure projection of three active peptides was predicted by I-TASSER (http://zhanglab.ccmb.med.umich.edu/ITASSER/).

\subsection{Bacteria Strains and Reagents}

All bacteria strains including reference strains and clinical isolates used in this study have been listed in Table S1. All antibiotics were obtained from the China Institute of Veterinary Drug Control. Other chemical compounds were purchased from TCI (Shanghai, China) 


\subsection{Antibacterial Activity Tests}

Minimum inhibitory concentrations (MICs) of peptides were determined by broth micro-dilution according to the CLSI2018 guideline [23]. Briefly, overnight strains were diluted 1:100 into Mueller-Hinton broth (MHB) and incubated at $37^{\circ} \mathrm{C}$ with sharking at $200 \mathrm{rpm}$ for $4 \mathrm{~h}$. Subsequently, varying concentrations of drugs were mixed with an equal volume of bacterial suspensions in MHB containing approximately $1.5 \times 10^{6}$ colony-forming units per $\mathrm{mL}$ in a sterilized 96 -well microtitre plate (Corning). After $18 \mathrm{~h}$ of incubation at $37^{\circ} \mathrm{C}$, MIC values were determined as the lowest concentrations of drugs with no visible growth of bacteria. For the minimum bactericidal concentration (MBC) assay, $50 \mu \mathrm{L}$ of mixture was taken out from clear well in MIC assays, resuspended in fresh media and plated onto Mueller-Hinton agar (MHA) overnight at $37^{\circ} \mathrm{C}$. The $\mathrm{MBC}$ is defined as the lowest concentration of drugs that killed $99.9 \%$ of the bacterial cells. Experiments were performed with two biological replicates.

Salts and serum stability. For assessing the effect of salts and serum on the activity of WRK-12, three salts (including $\mathrm{Na}^{+}, \mathrm{K}^{+}, \mathrm{Ca}^{2+}$, final concentration $10 \mathrm{mM}$ ), $10 \%$ fetal bovine serum (FBS) and Dulbecco's Modified Eagle Medium (DMEM) were added into MHB for a following MIC assay.

Thermal, $\mathrm{pH}$ and proteolytic stability. WRK-12 was preincubated at different temperatures (from 25 to $121^{\circ} \mathrm{C}$ ), $\mathrm{pH}$ (from 2 to 12 ) or proteases (pepsin, trypsin and papain, final concentration $10 \mathrm{mg} / \mathrm{mL}$ ) for $1 \mathrm{~h}$. Samples after $\mathrm{pH}$ treatment were readjusted to $\mathrm{pH}=7.2$ to determine the residual antibacterial activity by MIC tests. Samples after proteases treatment were heated at $80^{\circ} \mathrm{C}$ for $30 \mathrm{~min}$, and centrifuged at $13,000 \times g$ for $30 \mathrm{~min}$ to precipitate proteases, and the residual antibacterial activity of supernatants was tested by MIC analysis.

Lipopolysaccharides (LPS), lipids or NAC inhibition assay. The MICs of WRK-12 in the presence of increasing concentrations of lipopolysaccharide (LPS, 0 to $128 \mu \mathrm{g} / \mathrm{mL}$ ) from E. coli O111:B4 (Sigma) or various lipids (including phosphatidylcholine (PC), phosphatidylethanolamine (PE), phosphatidylglycerol (PG) and cardiolipin (CL) (0 to $16 \mu \mathrm{g} / \mathrm{mL}$, sigma) or NAC ( $N$-acetylcysteine, 0 to $2.5 \mathrm{mM}$ ) against $E$. coli 1F28 were determined as described above. Experiments were performed with biological replicates.

\subsection{Hemolysis Analysis}

Hemolytic activity of all peptides was evaluated based on previous studies [24,25]. Sheep red blood cells (RBCs) were washed with $0.9 \%$ saline two times, re-suspended to obtain $8 \%$ red blood cell suspension and then mixed with increasing concentrations of AMPs at $37^{\circ} \mathrm{C}$ for $1 \mathrm{~h}$. Sterilized PBS and double-distilled water $\left(\mathrm{ddH}_{2} \mathrm{O}\right)$ were used as blank and positive control, respectively. The absorption of released hemoglobin was measured at $576 \mathrm{~nm}$ by an Infinite M200 Microplate reader (Tecan, Männedorf, Switzerland). Hemolysis rate was calculated by comparing the absorbance of the sample and the positive control after subtracting the blank control.

\section{5. $C D$ Measurements}

Circular dichroism (CD) spectra of the peptides were recorded with a J-810 spectropolarimeter (Jasco, Tokyo, Japan) at $25^{\circ} \mathrm{C}$. The spectra were measured in $0.01 \mathrm{M}$ PBS, $50 \mu \mathrm{M}$ LPS or $50 \mathrm{mM}$ SDS (final concentration, $100 \mu \mathrm{g} / \mathrm{mL}$ ). The CD spectra were recorded at a wavelength of 190 to $260 \mathrm{~nm}$, and the data are expressed as mean residue ellipticity

\subsection{Outer Membrane Permeabilization}

E. coli $1 \mathrm{~F} 28$ were grown overnight at $37^{\circ} \mathrm{C}$ with shaking at $200 \mathrm{rpm}$. Bacterial cells were washed and resuspended with $5 \mathrm{mM}$ HEPES to an $\mathrm{OD}_{600}$ of 0.5 and incubated with fluorescent probe 1-N-phenylnaphthylamine (NPN, $0.1 \mu \mathrm{M})$ at $37^{\circ} \mathrm{C}$ in a humidified atmosphere for $30 \mathrm{~min}$ [26]. Subsequently, $190 \mu \mathrm{L}$ of probe-labelled cells were mixed with $10 \mu \mathrm{L}$ WRK-12 (0 to $128 \mu \mathrm{g} / \mathrm{mL}$ ) or colistin as a positive control $(128 \mu \mathrm{g} / \mathrm{mL})$ in a sterile 96 -well black plate. After incubation at $37^{\circ} \mathrm{C}$ 
in a humidified atmosphere for $60 \mathrm{~min}$, fluorescence intensity was measured on an Infinite M200 Microplate reader (Tecan, Männedorf, Switzerland) $(\lambda$ excitation $=350 \mathrm{~nm}$, 入emission $=420 \mathrm{~nm})$.

\subsection{Membrane Permeability Assay}

E. coli $1 \mathrm{~F} 28$ cells at exponential growth phase $\left(\mathrm{OD}_{600}=0.5\right)$ were incubated with propidium iodide (PI, $0.5 \mu \mathrm{M}$, Beyotime), followed by the addition of WRK-12 (0 to $128 \mu \mathrm{g} / \mathrm{mL})$ or colistin $(128 \mu \mathrm{g} / \mathrm{mL})$.

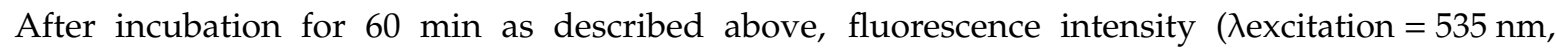
$\lambda$ emission $=615 \mathrm{~nm}$ ) was measured using a Microplate reader (Tecan, Männedorf, Switzerland).

\subsection{Cytoplasmic Membrane Potential}

A fluorescent probe $\operatorname{DiSC}_{3}(5)$ (Aladdin, Shanghai, China) was utilized to evaluate the effect of WRK-12 on bacterial membrane potential [27]. E. coli 1F28 cells were probed with 3,3'-dipropylthiadicarbocyanine iodide $\left(\operatorname{DiSC}_{3}(5), 0.5 \mu \mathrm{M}\right)$ for $30 \mathrm{~min}$, and then treated with WRK-12 ( 0 to $128 \mu \mathrm{g} / \mathrm{mL}$ ) or colistin $(128 \mu \mathrm{g} / \mathrm{mL}$ ) for $60 \mathrm{~min}$. Subsequently, the dissipated membrane potential was determined by monitoring the fluorescence intensity ( $\lambda$ excitation $=622 \mathrm{~nm}, \lambda$ emission $=670 \mathrm{~nm}$ ) using a Microplate reader (Tecan, Männedorf, Switzerland).

\subsection{ROS Measurements}

$2^{\prime}, 7^{\prime}$-Dichlorodihydrofluorescein diacetate (DCFH-DA, $10 \mu \mathrm{M}$ ) was incubated with E. coli 1F28 cells for $30 \mathrm{~min}$. After washing with $0.01 \mathrm{M}$ PBS, the probed cells were mixed with WRK-12 (0 to $128 \mu \mathrm{g} / \mathrm{mL})$ or colistin $(128 \mu \mathrm{g} / \mathrm{mL})$ for $60 \mathrm{~min}$. The ROS levels were assessed by monitoring the

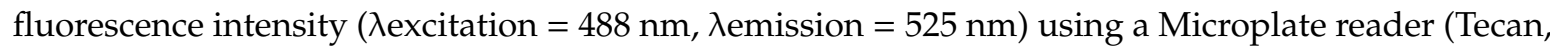
Männedorf, Switzerland).

\subsection{Prevention of Biofilm Formation}

The prevention of biofilm formation was assessed as described previously [28]. Briefly, bacteria $\left(1 \times 10^{5} \mathrm{CFUs}\right.$ per $\mathrm{mL}$ ) were exposed to WRK-12 solutions (with final concentrations ranging from 0.25 to $32 \mu \mathrm{g} / \mathrm{mL}$ ). As an untreated control, bacteria were exposed to MHB without drugs. After $24 \mathrm{~h}$ incubation at $37^{\circ} \mathrm{C}$ in a humidified atmosphere, planktonic bacteria were removed by phosphate buffer solution (PBS). Biofilms were fixed with methanol for $15 \mathrm{~min}$, then sucked out the fixative and air dry naturally. Then, biofilms were stained with $0.1 \%$ crystal violet for $15 \mathrm{~min}$, washed and dried naturally. Finally, 33\% acetic acid was used to dissolve crystal violet. The optical density at $570 \mathrm{~nm}$ was determined as a measure of biofilm mass.

\subsection{Statistical Analysis}

All data were shown as mean $\pm \mathrm{SD}$ from at least three triplicates. Statistical analysis was performed using GraphPad Prism $8\left({ }^{*} p<0.05,{ }^{* *} p<0.01,{ }^{* * *} p<0.001\right)$.

\section{Results and Discussion}

\subsection{Characterizations of Engineered Peptides}

A collection of tryptophan-rich linear peptides on the basis of MP196 (RWRWRW-NH ${ }_{2}$ ) was designed by increasing peptide length or positive charge or hydrophobicity, replacing amino acids and/or $\mathrm{N}$-terminal acetylation (Table 1 ). These peptides were synthesized via solid-phase peptide synthesis (SPPS), purified by reverse-phase high-performance liquid chromatography (RP-HPLC) (Figure S1) and validated by matrix-assisted laser desorption/ionization time-of-flight mass spectrometry (MALDI-TOF MS) (Figure S2). Chemical information and characterization of these engineered peptides are shown in Table 1 . All peptides were accurately obtained with the purifies higher than $95 \%$, and the molecular weights calculated by mass spectrometry are consistent with their theoretical molecular mass value, suggesting that all the engineered peptides were successfully 
synthesized. All engineered peptides belong to cationic AMPs, with 3 or 6 net charges. The percentage of acetonitrile at RP-HPLC elution was regarded as a relative measure of peptides' hydrophobicity. Accordingly, the majority of engineered peptides, except WK-6, exhibited higher hydrophobicity than MP196. The hydrophobicity order was listed as follows: WRK-12 > WL-9 > WR-6 > WV-9 $>$ KW-6 > WKK-12 > WR-12 > MP196 > WK-6.

Table 1. Design of tryptophan-rich amphiphilic peptides and their key physicochemical parameters.

\begin{tabular}{|c|c|c|c|c|c|c|c|c|}
\hline Name & $\begin{array}{l}\text { Sequence } \\
(N \rightarrow C)\end{array}$ & Formula & MW & $\begin{array}{l}\text { Net } \\
\text { Charge }\end{array}$ & $\mathrm{pI}^{a}$ & $\mathbf{H}^{b}$ & $\begin{array}{c}\text { Purity } \\
(\%)\end{array}$ & $\begin{array}{c}\operatorname{MIC}^{c} \\
(\mu \mathrm{g} / \mathrm{mL})\end{array}$ \\
\hline MP196 & $\begin{array}{l}\text { RWRWRW- } \\
\mathrm{NH}_{2}\end{array}$ & $\mathrm{C}_{51} \mathrm{H}_{69} \mathrm{~N}_{19} \mathrm{O}_{6}$ & 1044.24 & +3 & 12.30 & 30.275 & 99.15 & $>64$ \\
\hline WR-6 & $\begin{array}{c}\text { WRWRWR- } \\
\mathrm{NH}_{2}\end{array}$ & $\mathrm{C}_{51} \mathrm{H}_{69} \mathrm{~N}_{19} \mathrm{O}_{6}$ & 1044.24 & +3 & 12.30 & 34.157 & 95.31 & $>64$ \\
\hline KW-6 & $\begin{array}{c}\text { KWKWKW- } \\
\mathrm{NH}_{2}\end{array}$ & $\mathrm{C}_{51} \mathrm{H}_{69} \mathrm{~N}_{13} \mathrm{O}_{6}$ & 960.20 & +3 & 10.30 & 31.903 & 95.98 & $>64$ \\
\hline WK-6 & $\begin{array}{c}\text { WKWKWK- } \\
\mathrm{NH}_{2}\end{array}$ & $\mathrm{C}_{51} \mathrm{H}_{69} \mathrm{~N}_{13} \mathrm{O}_{6}$ & 960.20 & +3 & 10.30 & 25.517 & 98.83 & $>64$ \\
\hline WL-9 & $\begin{array}{l}\text { WRLWRLW } \\
\text { RL-NH }_{2}\end{array}$ & $\mathrm{C}_{69} \mathrm{H}_{102} \mathrm{~N}_{22} \mathrm{O}_{9}$ & 1383.72 & +3 & 12.30 & 35.818 & 95.59 & 8 \\
\hline WV-9 & $\begin{array}{c}\text { WKVWKVW } \\
\text { KV-NH }_{2}\end{array}$ & $\mathrm{C}_{66} \mathrm{H}_{96} \mathrm{~N}_{16} \mathrm{O}_{9}$ & 1257.60 & +3 & 10.30 & 32.456 & 99.22 & $>64$ \\
\hline WR-12 & $\begin{array}{l}\text { WRLRWRLRW } \\
\text { RLR-NH }_{2}\end{array}$ & $\mathrm{C}_{87} \mathrm{H}_{138} \mathrm{~N}_{34} \mathrm{O}_{12}$ & 1852.29 & +6 & 12.70 & 30.329 & 99.40 & 2 \\
\hline WRK-12 & $\begin{array}{l}\text { Ac-WRLRWKT } \\
\text { RWRLK-NH }\end{array}$ & $\mathrm{C}_{87} \mathrm{H}_{136} \mathrm{~N}_{30} \mathrm{O}_{14}$ & 1826.25 & +6 & 12.48 & 36.513 & 98.79 & 2 \\
\hline WKK-12 & $\begin{array}{l}\text { Ac-WKVKWKV } \\
\text { KWKVK-NH }_{2}\end{array}$ & $\mathrm{C}_{86} \mathrm{H}_{134} \mathrm{~N}_{22} \mathrm{O}_{13}$ & 1684.17 & +6 & 10.70 & 31.424 & 95.27 & 64 \\
\hline
\end{tabular}

\footnotetext{
${ }^{a}$ The isoelectric point (pI) values of derivatives were determined by ExPASy (http://web.expasy.org/compute_pi/).

${ }^{b}$ Hydrophobicity was calculated by the percent of acetonitrile in water, $0.1 \%(v / v)$ trifluoroacetic acid (TFA) at HPLC elution. The higher percent acetonitrile, the higher the hydrophobicity. ${ }^{c}$ Antibacterial activity of peptides against MDR E. coli B2 was tested. Four AMPs with antibacterial activity against MDR E. coli B2 were highlighted in green.
}

\subsection{Broad-Spectrum Antibacterial Activity of Engineered Peptides In Vitro}

Subsequently, we assessed the antibacterial activity of these peptides against a multidrug-resistant (MDR) strain E. coli B2, which is almost resistant to all clinically used antibiotics. MIC results (Table 1) revealed that three repeats of dipeptide such as MP196, WR-6 (WRWRWR-NH $_{2}, \mathrm{KW}^{-6}$

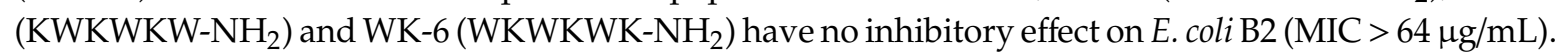
The introduction of hydrophobic Leucine (Leu, L) or Valine (Val, V) leads to two new nonapeptides WL-9 (WRLWRLWRL-NH ${ }_{2}$ ) and WV-9 (WKVWKVWKV-NH 2 ). Interestingly, WL-9 exerted modest antibacterial activity (MIC, $8 \mu \mathrm{g} / \mathrm{mL}$ ), whereas WV-9 is inactive (MIC > $64 \mu \mathrm{g} / \mathrm{mL})$.

It has been suggested that cationicity and acetylation at $N$-terminal contribute to improve the activity of AMPs [29]; Therefore, three positive amino acids and/or acetylation at $N$-terminal were further introduced on the basis of two nonapeptides. As a consequence, we constructed three novel dodecapeptides including WR-12, WRK-12 and WKK-12 with acetylation at the N-terminus and amidation at the C-terminus. As expected, insertion of three positive amino acids in WL-9 (produce WR-12 or WRK-12) significantly increased its antibacterial activity with MICs decreasing by 4-fold change.

The wheel diagram showed these four active AMPs including WL-9, WR-12, WRK-12 and WKK-12 (Figure 1A), which exhibited imperfect amphiphilic structures that possessed interrupted hydrophobic and cationic faces (Figure 1B). Interestingly, although WRK-12 displayed high hydrophobicity, the solubility test showed that only WRK-12 has the highest solubility in 0.01 M PBS or water, whereas the other three peptides are slightly soluble in water. The introduction of Threonine (Thr, T) in WRK-12, an uncharged polar amino acid, may account for this paradox. Prior studies have illustrated that $N$-terminus acetylation has a critical effect on both peptide secondary structure and penetration ability on the bacterial membrane, as well as its in vivo efficacy [30,31]. Considering these points, WRK-12 and WKK-12 were chosen as potential candidates for our next study. 

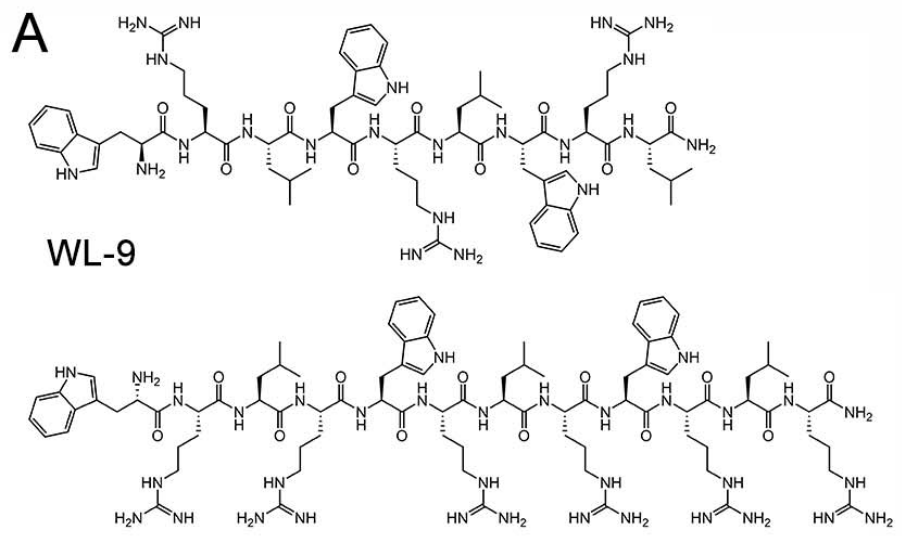

WR-12

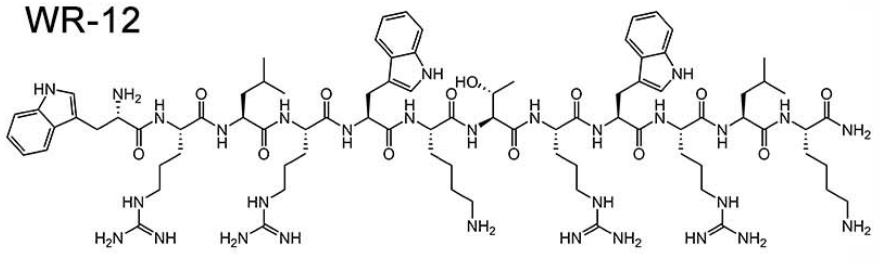

WRK-12

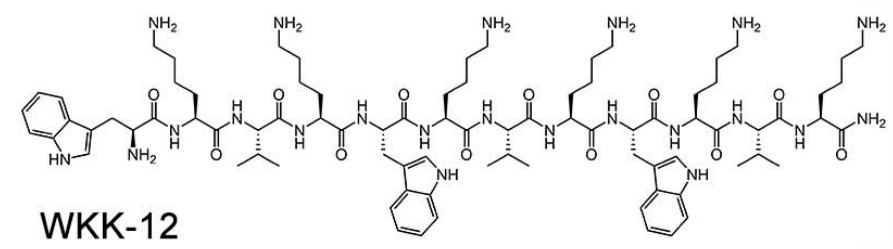

B
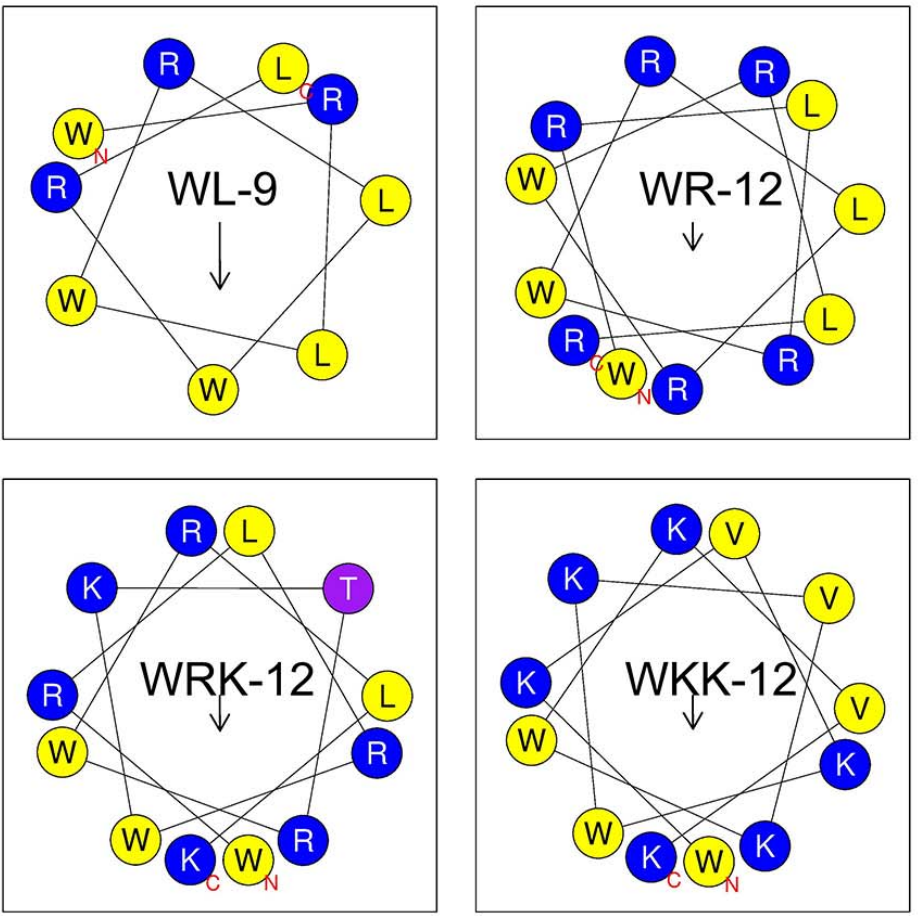

Figure 1. Design of tryptophan-rich amphiphilic antibacterial peptides. (A) Chemical structures of four active AMPs (WL-9, WR-12, WRK-12 and WKK-12). (B) Helical wheel projections of four AMPs. The potentially charged residues, hydrophobicity residues and uncharged residues were marked as blue, yellow and pink, respectively. The longer the arrow length, the greater the relative hydrophobic moments in the figure. 
MIC tests showed that WRK-12 and WKK-12 displayed antibacterial activity against MDR E. coli B2 with MIC values of 2 and $64 \mu \mathrm{g} / \mathrm{mL}$, respectively. Subsequently, we investigated the antibacterial spectrum of WRK-12 and WKK-12 in a panel of MDR bacterial isolates. As shown in Table 2, we found that WRK-12 showed the broad-spectrum antibacterial activity against all test strains with MIC values from 2 to $4 \mu \mathrm{g} / \mathrm{mL}$ and MBC values from 2 to $8 \mu \mathrm{g} / \mathrm{mL}$. These strains include hard-to-treat Gram-positive bacteria such as MRSA and VRE, MDR Gram-negative bacteria that are resistant to the last resort of clinically available antibiotics such as carbapenems, colistin and tigecycline. Specifically, for both $m c r-1$ and bla $a_{\text {NDM-5 }}$ carrying colistin and carbapenems-resistant E. coli B2 (MIC of colistin, $8 \mu \mathrm{g} / \mathrm{mL}$ ) and tet(X4)-positive tigecycline E. coli B3-1 (MIC of tigecycline, $32 \mu \mathrm{g} / \mathrm{mL}$ ), WRK-12 also displayed potent activity, suggesting that the activity of WRK-12 is independent of these two resistance mechanisms. Considering the urgent need of novel antimicrobial agents for recent reported tigecycline-resistant Gram-negative bacteria in clinic, we next focused our insight on these strains. We investigated the activity of WRK-12 and WKK-12 against 11 tigecycline-resistant clinical isolates from a swine farm in 2019 (Table 3). Excitingly, WRK-12 displayed great antibacterial activity for all test strains, including important foodborne pathogen Shigella.

Table 2. Antibacterial spectrum of two amphiphilic peptides against a panel of pathogenic bacteria (MIC or MBC, $\mu \mathrm{g} / \mathrm{mL}$ ).

\begin{tabular}{|c|c|c|c|c|c|c|c|}
\hline \multirow{2}{*}{ Organism and Genotype } & \multicolumn{2}{|c|}{ WRK-12 } & \multirow{2}{*}{ WKK-12 } & \multirow[t]{2}{*}{ AMP } & \multirow{2}{*}{$\begin{array}{c}\text { VAN } \\
\text { MIC }\end{array}$} & \multirow[t]{2}{*}{ COL } & \multirow[t]{2}{*}{ TIG } \\
\hline & MIC & MBC & & & & & \\
\hline \multicolumn{8}{|l|}{ Gram-positive bacteria } \\
\hline S. aureus ATCC 29213 & 4 & 4 & 128 & 0.25 & 0.5 & 16 & 0.125 \\
\hline MRSA T144 & 2 & 2 & 64 & 32 & 1 & 128 & 2 \\
\hline S. aureus $215\left(c f r+\mathrm{LZD}^{\mathrm{R}}\right)$ & 2 & 2 & 64 & 64 & 1 & 64 & 1 \\
\hline E. faecalis A4 (VRE) & 4 & 8 & 64 & 32 & $>128$ & 128 & 0.125 \\
\hline \multicolumn{8}{|l|}{ Gram-negative bacteria } \\
\hline E. coli ATCC 25922 & 4 & 8 & 128 & 8 & 128 & 0.5 & 0.125 \\
\hline E. coli $\mathrm{B} 2\left(m c r-1+b l a_{\mathrm{NDM}-5}\right)$ & 4 & 4 & $>128$ & $>128$ & 128 & 8 & 2 \\
\hline E. coli B3-1 (tet $(\mathrm{X} 4))$ & 2 & 2 & 64 & $>128$ & 64 & 0.25 & 32 \\
\hline E. coli 1F28 (tet (X4)) & 2 & 8 & 64 & $>128$ & 128 & 0.25 & 32 \\
\hline S. enteritidis ATCC 13076 & 4 & 4 & 64 & 8 & 128 & 0.25 & 0.125 \\
\hline
\end{tabular}

ATCC, American Type Culture Collection; VRE: vancomycin-resistant enterococci, LZD ${ }^{\mathrm{R}}$ : linezolid-resistant. AMP, ampicillin; VAN, vancomycin; COL, colistin; TIG, tigecycline.

Table 3. Antibacterial activity of amphiphilic peptides against tigecycline-resistant clinical isolates $(\mathrm{MIC}, \mu \mathrm{g} / \mathrm{mL})$.

\begin{tabular}{ccccc}
\hline Clinical Isolates & Origin & WRK-12 & WKK-12 & Tigecycline \\
\hline E. coli 1N28 & Nasal swab & 8 & 64 & 32 \\
E. coli 1N31 & & 16 & 64 & 128 \\
E. coli 1C1 & Dust & 4 & 64 & 32 \\
E. coli 1F16 & Feces & 4 & 64 & $>64$ \\
E. coli 1F31 & & 4 & 64 & 32 \\
E. coli 1A34 & Anal swab & 2 & 64 & 16 \\
E. coli 2A19 & & 16 & 128 & 8 \\
E. coli 2W25 & Water & 4 & 64 & 64 \\
Shigella 1F25 & Feces & 8 & 64 & 8 \\
\hline
\end{tabular}

The secondary structure of the engineered peptides was tested by CD spectroscopy. As shown in Figure 2, WRK-12 exhibited a complete beta sheet conformation in phosphate buffer solution (PBS). LPS is one of important components in the Gram-negative bacterial outer membrane [32], and sodium dodecyl sulfate (SDS) micelle solution was used that mimicked negatively charged prokaryotic membrane-comparable environments. In the presence of $50 \mu \mathrm{M}$ LPS and $50 \mathrm{mM}$ SDS, 
the proportion of random and $\alpha$-helical WRK-12 increased. This result indicated that the secondary structure of WRK-12 would present in hybrid form as it interacts with the bacterial membrane.

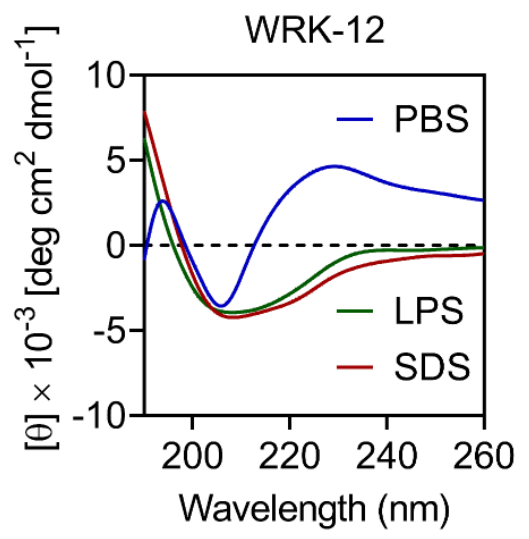

\begin{tabular}{llll}
\hline \multirow{2}{*}{$\begin{array}{l}\text { Secondary } \\
\text { structure }\end{array}$} & \multicolumn{3}{l}{ WRK-12 in solutions } \\
\cline { 2 - 4 } & PBS & LPS & SDS \\
\hline Helix & 0.1 & 9.8 & 18.8 \\
Beta & 99.9 & 46.0 & 36.4 \\
Turn & 0 & 0 & 0 \\
Random & 0 & 44.2 & 44.7 \\
Total & 100 & 100 & 100 \\
\hline
\end{tabular}

Figure 2. Circular dichroism (CD) spectra of WRK-12 in PBS (10 mM, pH 7.4), Lipopolysaccharide (LPS) $(50 \mu \mathrm{M})$ and SDS (50 mM). The values from three scans were averaged per sample, and the peptide concentrations were fixed at $100 \mu \mathrm{g} / \mathrm{mL}$.

\subsection{A Desirable Safety and Stability of WRK-12 against Bacteria}

The hemolytic activity and instability of peptides are important challenges that hinder the clinical application of drugs [33]. In our study, hemolytic analysis showed that WRK-12 had the dispensable and lowest hemolytic activity $(<5 \%$ at $128 \mu \mathrm{g} / \mathrm{mL}$ ) on mammalian RBCs compared with the other three active AMPs (Figure 3), indicating higher selectivity of WRK-12 for bacteria other than mammalian cells. Although WR-12 showed comparable antibacterial activity with WRK-12, it displayed more than $50 \%$ of the hemolytic rate at $128 \mu \mathrm{g} / \mathrm{mL}$.

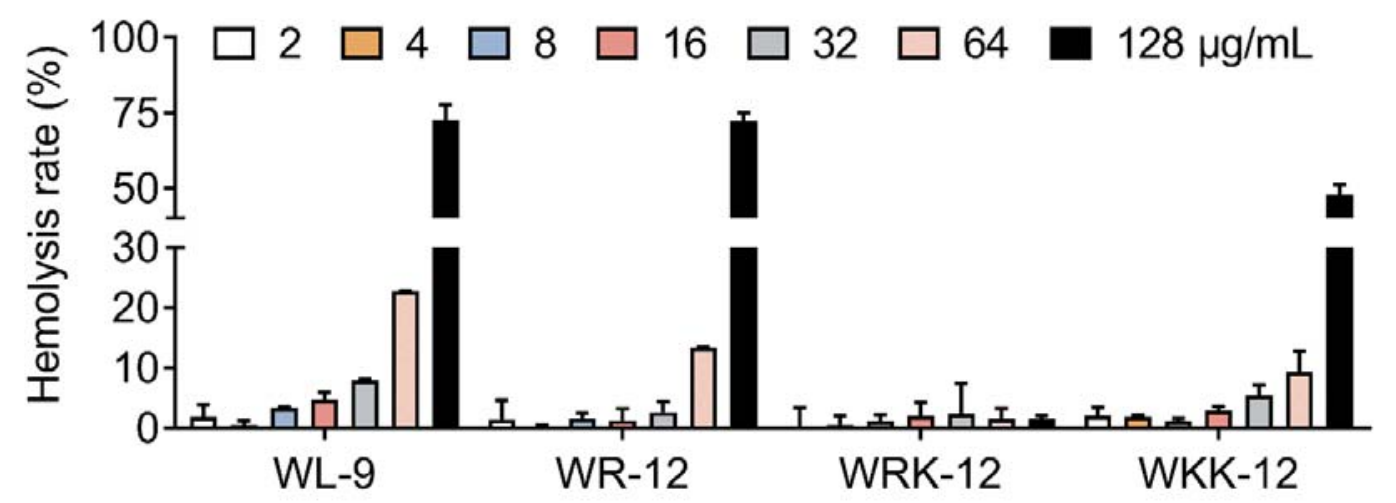

Figure 3. Hemolytic activity of four active peptides against mammalian red blood cells (RBCs).

Sterilized PBS (10 mM) and $\mathrm{ddH}_{2} \mathrm{O}$ were used as a negative control and positive control, respectively.

Great stability of antimicrobial peptides is a critical prerequisite for its in vivo efficacy. Thus, we evaluated the antibacterial activity of WRK-12 and WKK-12 against tigecycline resistant E. coli 1F28 and 1A34 in the presence of salt ions, serum and Dulbecco's Modified Eagle's Medium (DMEM) (Table 4). There was not any loss of activity in the presence of monovalent cations $\left(\mathrm{Na}^{+}\right.$and $\left.\mathrm{K}^{+}\right)$, whereas divalent cation $\mathrm{Ca}^{2+}, 10 \%$ serum or DMEM mildly reduced the activity of WRK-12 with the MICs increasing by 2 to 4 -fold. The weakened activity by the divalent cation indicated that the action of WRK-12 may be correlated with membrane damage, because the outer membrane of Gram-negative bacteria could be stabilized with divalent cations particularly $\mathrm{Ca}^{2+}$ and $\mathrm{Mg}^{2+}$ [34]. By contrast, $\mathrm{Na}^{+}$, $\mathrm{Ca}^{2+}, 10 \%$ serum or DMEM sharply impaired the weak antibacterial effect of WKK-12 against two tested isolates. 
Table 4. Salt and serum stability of two amphiphilic peptides (MIC, $\mu \mathrm{g} / \mathrm{mL}$ ).

\begin{tabular}{ccc}
\hline Strains & WRK-12 & WKK-12 \\
\hline E. coli 1F28 & 2 & 64 \\
$+\mathrm{Na}^{+}(10 \mathrm{mM})$ & 2 & $>128$ \\
$+\mathrm{K}^{+}(10 \mathrm{mM})$ & 2 & 64 \\
$+\mathrm{Ca}^{2+}(10 \mathrm{mM})$ & 8 & $>128$ \\
$+10 \%$ Serum & 4 & $>128$ \\
$+10 \%$ DMEM & 4 & $>128$ \\
E. coli $1 \mathrm{~A} 34$ & 2 & 64 \\
$+\mathrm{Na}^{+}(10 \mathrm{mM})$ & 2 & $>128$ \\
$+\mathrm{K}^{+}(10 \mathrm{mM})$ & 2 & 64 \\
$+\mathrm{Ca} \mathrm{a}^{2+}(10 \mathrm{mM})$ & 4 & $>128$ \\
$+10 \%$ Serum & 4 & $>128$ \\
$+10 \%$ DMEM & 4 & $>128$ \\
\hline
\end{tabular}

In addition, medium containing 10\% serum and DMEM was used to simulate an in vivo matrix environment. Only 2 to 4 -fold increase of MIC values were found in these conditions. Next, we also assessed the thermal, $\mathrm{pH}$ and proteolytic stability of WRK-12. Surprisingly, WRK-12 completely retained its activity after treatment under $100{ }^{\circ} \mathrm{C}$ or $\mathrm{pH}$ ( 2 to 10) for $1 \mathrm{~h}$ (Figure $\left.4 \mathrm{~A}, \mathrm{~B}\right)$, indicating that WRK-12 possesses great thermal and $\mathrm{pH}$ resistance. In contrast, a 50\% activity reduction after exposure to $121^{\circ} \mathrm{C}$ or alkaline environment $(\mathrm{pH}=12)$ was observed. In the proteolytic stability study, we found that WRK-12 was resistant to pepsin treatment, but sensitive to trypsin and papain (Figure 4C). High percentage of cationic amino acids in WRK-12 may account for this result. Together, these data suggested the great salt ions, serum, thermal and pH stability of WRK-12.
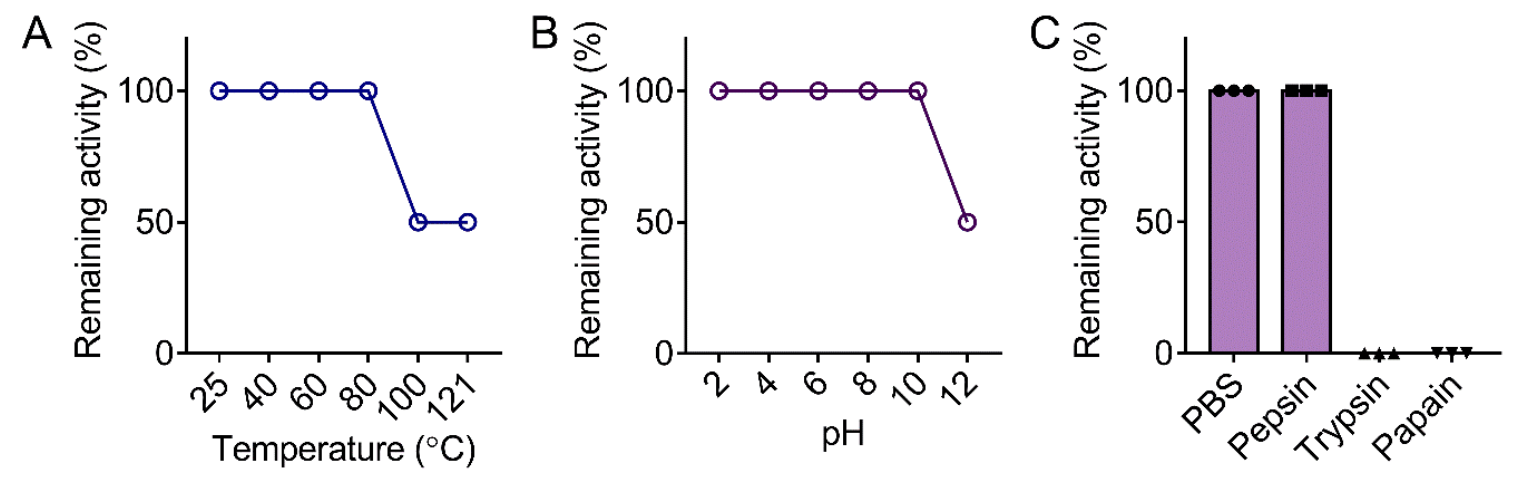

Figure 4. Thermal, $\mathrm{pH}$ and proteolytic stability of WRK-12 against E. coli 1F28. Remaining activity (\%) of WRK-12 against E. coli 1F28 after treatment with varying temperature (A, from 25 to $\left.121{ }^{\circ} \mathrm{C}\right), \mathrm{pH}(\mathbf{B}$, from 2 to 12) and three proteases (C).

\subsection{WRK-12 Targets LPS and Bacteria-Specific Phospholipids}

Having shown the activity and stability of WRK-12, we set out to elucidate its bactericidal targets. Previous studies have demonstrated that cationic AMPs such as MSI-78 and LL-37 can disrupt the bacterial lipid bilayer structure through their electrostatic interactions with the polar headgroups $[35,36]$. Considering that WRK-12 is a cationic antibacterial peptide, we hypothesize that WRK-12 may damage the bacterial membrane through targeting the specific components of the bacterial membrane. To test this, we determined the effect of exogenous LPS or phospholipid supplements on the antibacterial activity of WRK-12 against E. coli 1F28. Consequently, we found that addition of LPS weakened WRK-12 activity in a dose-dependent manner (Figure 5A), suggesting that LPS is a potential target of WRK-12. In addition to LPS, phospholipids including PE, phosphatidylglycerol (PG) and cardiolipin (CL) are important components of the bacterial plasma membrane, whereas phosphatidylcholine (PC) only presents in mammalian cell membranes [37]. Thus, we next performed a phospholipid competitive 
inhibition assay to assess the effect of exogenous lipids on WRK-12 activity. As a result, PG and CL drastically increased the MIC values of WRK-12 (16-fold at $16 \mu \mathrm{g} / \mathrm{mL}$ PG or CL), PE mildly impaired WRK-12 activity and no MIC changes were observed for CL (Figure 5B). These results implied that WRK-12 exerted the activity through binding to LPS in the outer membrane, as well as PG and CL that were located in the bacterial cytoplasmic membrane. Meanwhile, the notion that PG and CL have a lower proportion in mammalian cell membranes give an explanation on its high selectivity on bacteria. Nevertheless, direct binding affinity assays between WRK-12 and these potential targets are still required to further strengthen these findings.
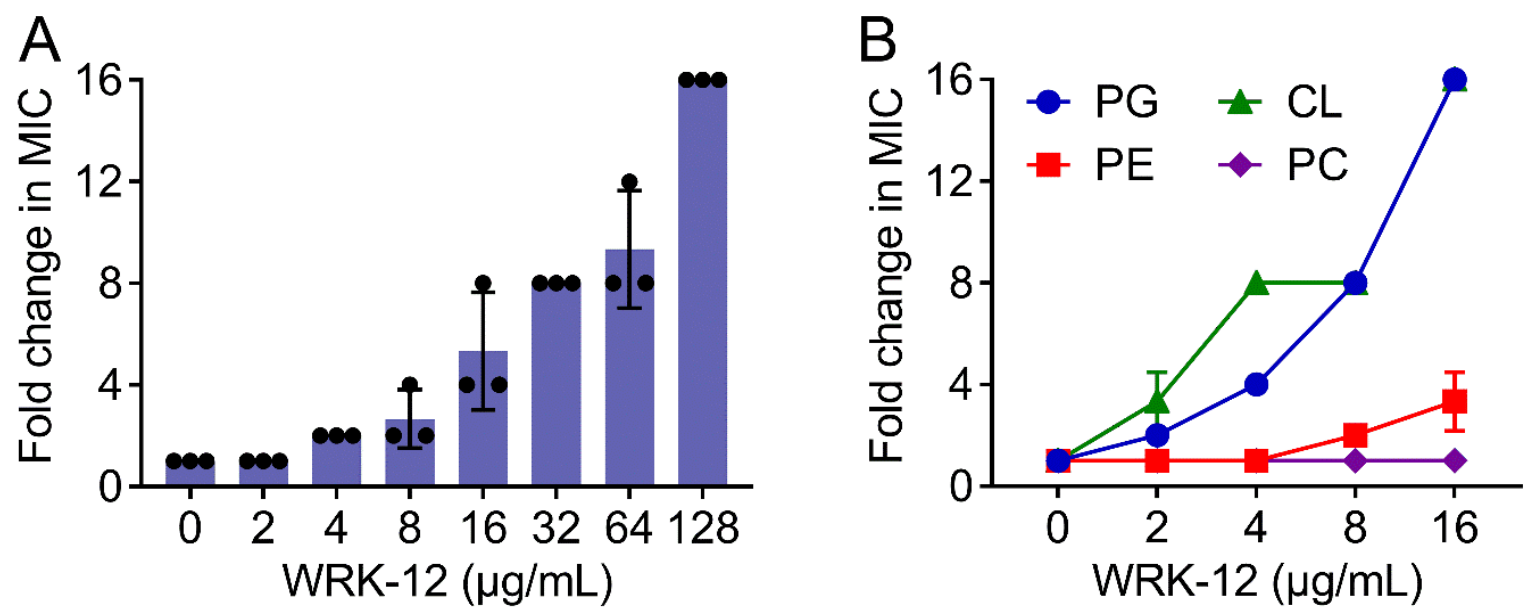

Figure 5. WRK-12 targets LPS and various phospholipids of the bacterial membrane. (A) Exogenous LPS from E. coli O111:B4 dose-dependent decreases the antibacterial activity of WRK-12 against $E$. coli 1F28, determined by chequerboard broth microdilution tests. (B) Exogenous lipids including PG, CL and PE except PC increase the MIC values of WRK-12 against E. coli 1F28, determined by chequerboard broth microdilution tests.

\subsection{WRK-12 Increases Membrane Permeability, Dissipates Membrane Potential and Induces ROS Production}

To further elucidate membrane damage caused by WRK-12, we used a fluorescence probe $1-N$-phenylnaphthylamine (NPN) to assess the effect of WRK-12 on the outer membrane permeability of E. coli. As shown in Figure 6A, WRK-12 at $128 \mu \mathrm{g} / \mathrm{mL}$ caused a significant fluorescence release, which was five-fold higher than colistin $(128 \mu \mathrm{g} / \mathrm{mL})$, indicating that WRK-12 strongly disrupted outer membrane permeability than colistin. Then, nucleic acid fluorescent dye propidium iodide (PI) was employed to evaluate the whole membrane permeability. As a result, WRK-12 led to a dose-dependent increase of PI fluorescence, implying a remarkable damage to the bacterial membrane (Figure 6B). By contrast, colistin $(128 \mu \mathrm{g} / \mathrm{mL})$ showed a week fluorescence increase, similar to $4 \mu \mathrm{g} / \mathrm{mL}$ WRK-12. Consistently, membrane disruption has been suggested as one of crucial mechanisms of action for AMPs killing [38]. Besides, WRK-12 significantly dissipated membrane potential $(\Delta \Psi)$ (Figure $6 \mathrm{C})$, which was critical component of bacterial proton motive force [39]. ROS mediated killing has been evidenced to be important for bactericidal antibiotics [40]. Consistently, WRK-12 triggered the production of ROS in a concentration-dependent manner (Figure 6D). In agreement with this observation, ROS scavenger NAC abolished the antibacterial activity of WRK-12 with MIC increased by 6-fold at $2.5 \mathrm{mM}$ (Figure 7), suggesting that production of ROS is crucial for WRK-12 activity against MDR pathogens. 

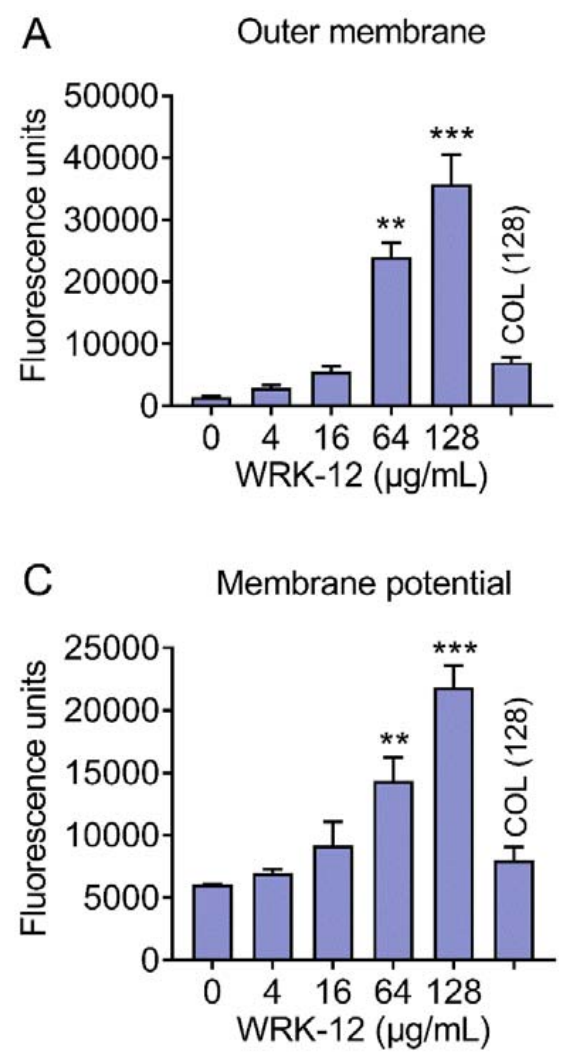

B Membrane permeability

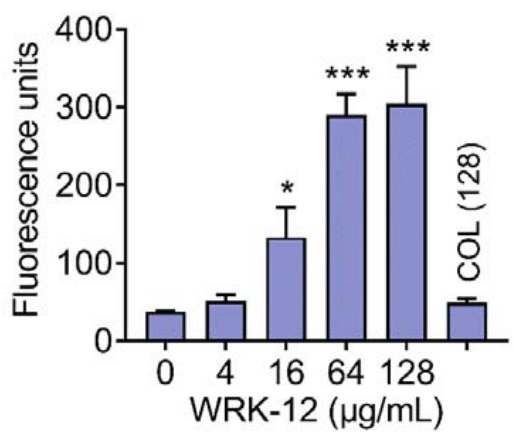

D

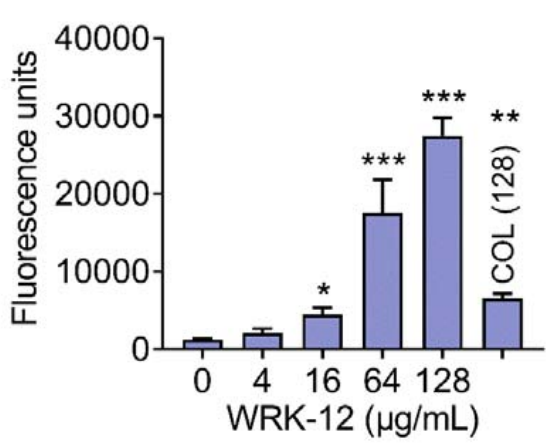

Figure 6. Bactericidal mechanisms of WRK-12 against multidrug resistant E. coli. (A and B) WRK-12 increases outer membrane and cytoplasmic membrane permeability in a dose-dependent manner. Permeability of outer membrane (A) and the whole membrane permeability (B) were assessed with fluorescence probes $1-N$-phenylnaphthylamine (NPN, excitation $350 \mathrm{~nm}$ and emission $420 \mathrm{~nm}$ ) and propidium iodide (PI, excitation $535 \mathrm{~nm}$ and emission $615 \mathrm{~nm}$ ), respectively, after exposure

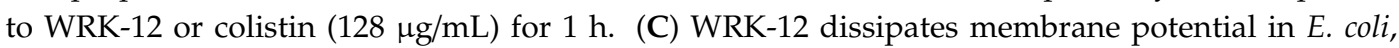
probed by monitoring fluorescence intensity of 3,3'-dipropylthiadicarbocyanine iodide (DiSC3(5), excitation $622 \mathrm{~nm}$ and emission $670 \mathrm{~nm}$ ). (D) WRK-12 triggers the production of ROS, determined by $2^{\prime}, 7^{\prime}$-dichlorodihydrofluorescein diacetate (DCFH-DA, excitation $488 \mathrm{~nm}$ and emission $525 \mathrm{~nm}$ ). All data were presented as mean $\pm \mathrm{SD}$, and significance was determined by non-parametric one-way ANOVA. ${ }^{*} p<0.05,{ }^{* *} p<0.01,{ }^{* * *} p<0.001$. Colistin $(128 \mu \mathrm{g} / \mathrm{mL})$ was used as a control.

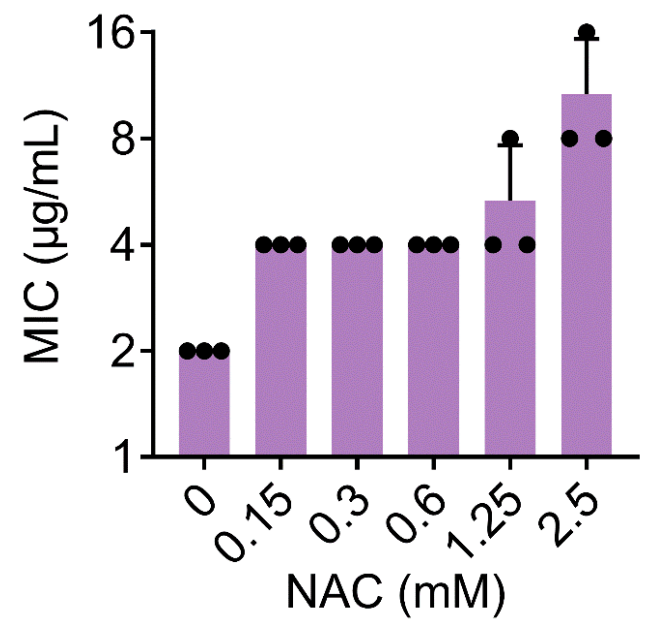

Figure 7. ROS scavenger NAC abolishes the antibacterial activity of WRK-12. MIC values of WRK-12 against $E$. coli $1 \mathrm{~F} 28$ in the presence of increasing concentrations of NAC ( $N$-acetylcysteine) were determined. Data were presented as mean \pm SD from three independent experiments. 


\subsection{WRK-12 Inhibits Biofilm Formation}

Biofilms produced by bacteria play a critical role in its pathogenicity and the development of drug resistance and have been implicated in chronic infections. Recent study has highlighted the possible use of AMPs to prevent biofilm formation or to treat established biofilms [28]. Intriguingly, WRK-12 dose-dependently inhibited the formation of biofilms by tigecycline-resistant $E$. coli 1F28 (Figure 8). Notably, a significant inhibition effect of WRK-12 on biofilm formation could be observed even though at a low concentration of drug $(0.5 \mu \mathrm{g} / \mathrm{mL})$. The biofilm mass, as measured using crystal violet staining after $24 \mathrm{~h}$, drastically reduced after exposure to $2 \mu \mathrm{g} / \mathrm{mL}$ or higher concentrations of WRK-12. These results indicated that WRK-12 has a beneficial effect on the inhibition of biofilm formation.

\section{Biofilm inhibition}

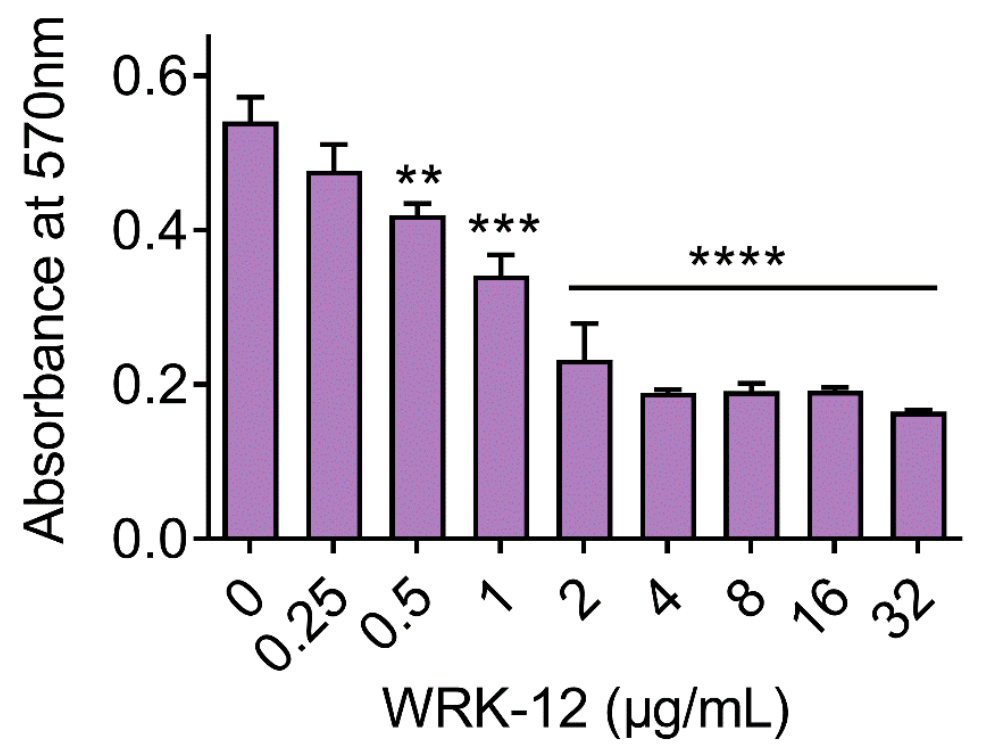

Figure 8. WRK-12 inhibits the formation of E. coli 1F28 biofilm in a concentration-dependent manner. Data were shown as mean \pm SD from three independent experiments. ${ }^{* *} p<0.01,{ }^{* * *} p<0.001$, **** $p<0.0001$, determined by non-parametric one-way ANOVA.

\section{Conclusions}

The emergence and prevalence of MDR pathogens call for novel and effective antimicrobial agents. In this study, we designed a series of tryptophan-rich amphiphilic peptides and investigated their antibacterial effect on MDR bacteria. A stable and potent dodecapeptide termed WRK-12 was identified, which exerts excellent activity against various pathogenic bacteria including carbapenems, colistin and tigecycline-resistant Gram-negative bacteria. Furthermore, WRK-12 displays low hemolytic activity and high salt or serum stability. Mechanical studies revealed that WRK-12 causes membrane damage and over-production of ROS through targeting LPS and bacterial-specific lipids. Collectively, the discovery of potent antimicrobial leads offers a novel therapeutic strategy to combat the increasing MDR bacteria.

Supplementary Materials: The following are available online at http://www.mdpi.com/2076-2607/8/9/1398/s1, Table S1: Bacterial strains used in this study; Figure S1: HPLC spectra of engineered antimicrobial peptides on the basis of MP196; Figure S2: MS spectra of engineered antimicrobial peptides on the basis of MP196.

Author Contributions: Z.W. and Y.L. designed this study. Y.L. and J.S. performed all experiments. Y.L., J.S., Z.T., Y.J. and K.Y. analyzed the data. Y.L. and J.S. wrote the manuscript. All authors have read and agreed to the published version of the manuscript. 
Funding: This work was supported by the National Key Research and Development Program of China (2018YFA0903400), Natural Science Foundation of Jiangsu Province of China (BK20190893), China Postdoctoral Science Foundation (2019M651984), A Project Funded by the Priority Academic Program Development of Jiangsu Higher Education Institutions (PAPD) and Lift Engineering of Young Talents of Jiangsu Association for Science and Technology.

Conflicts of Interest: The authors declare no conflict of interest.

\section{References}

1. Peleg, A.Y.; Hooper, D.C. Hospital-acquired infections due to gram-negative bacteria. N. Engl. J. Med. 2010, 362, 1804-1813. [CrossRef] [PubMed]

2. Maldonado, R.F.; Sá-Correia, I.; Valvano, M.A. Lipopolysaccharide modification in Gram-negative bacteria during chronic infection. FEMS Microbiol. Rev. 2016, 40, 480-493. [CrossRef] [PubMed]

3. Koulenti, D.; Song, A.; Ellingboe, A.; Abdul-Aziz, M.H.; Harris, P.; Gavey, E.; Lipman, J. Infections by multidrug-resistant Gram-negative Bacteria: What's new in our arsenal and what's in the pipeline? Int. J. Antimicrob. Agents 2019, 53, 211-224. [CrossRef] [PubMed]

4. Li, X.Z.; Plésiat, P.; Nikaido, H. The challenge of efflux-mediated antibiotic resistance in Gram-negative bacteria. Clin. Microbiol. Rev. 2015, 28, 337-418. [CrossRef]

5. Cillóniz, C.; Dominedò, C.; Torres, A. Multidrug resistant gram-negative bacteria in community-acquired Pneumonia. Crit. Care 2019, 23, 79. [CrossRef]

6. Kumarasamy, K.K.; Toleman, M.A.; Walsh, T.R.; Bagaria, J.; Butt, F.; Balakrishnan, R.; Chaudhary, U.; Doumith, M.; Giske, C.G.; Irfan, S. Emergence of a new antibiotic resistance mechanism in India, Pakistan, and the UK: A molecular, biological, and epidemiological study. Lancet Infect. Dis. 2010, 10, $597-602$. [CrossRef]

7. Liu, Y.-Y.; Wang, Y.; Walsh, T.R.; Yi, L.-X.; Zhang, R.; Spencer, J.; Doi, Y.; Tian, G.; Dong, B.; Huang, X.; et al. Emergence of plasmid-mediated colistin resistance mechanism MCR-1 in animals and human beings in China: A microbiological and molecular biological study. Lancet Infect. Dis. 2016, 16, 161-168. [CrossRef]

8. Shen, Y.; Zhang, R.; Schwarz, S.; Wu, C.; Shen, J.; Walsh, T.R.; Wang, Y. Farm animals and aquaculture: Significant reservoirs of mobile colistin resistance genes. Environ. Microbiol. 2020, 22, 2469-2484. [CrossRef]

9. Poirel, L.; Jayol, A.; Nordmann, P. Polymyxins: Antibacterial activity, susceptibility testing, and resistance mechanisms encoded by plasmids or chromosomes. Clin. Microbiol. Rev. 2017, 30, 557-596. [CrossRef]

10. Sun, J.; Chen, C.; Cui, C.Y.; Zhang, Y.; Liu, X.; Cui, Z.H.; Ma, X.Y.; Feng, Y.; Fang, L.X.; Lian, X.L.; et al. Plasmid-encoded tet $(\mathrm{X})$ genes that confer high-level tigecycline resistance in Escherichia coli. Nat. Microbiol. 2019, 4, 1457-1464. [CrossRef]

11. He, T.; Wang, R.; Liu, D.; Walsh, T.R.; Zhang, R.; Lv, Y.; Ke, Y.; Ji, Q.; Wei, R.; Liu, Z. Emergence of plasmid-mediated high-level tigecycline resistance genes in animals and humans. Nat. Microbiol. 2019, 4, 1450-1456. [CrossRef]

12. Wang, J.; Dou, X.; Song, J.; Lyu, Y.; Zhu, X.; Xu, L.; Li, W.; Shan, A. Antimicrobial peptides: Promising alternatives in the post feeding antibiotic era. Med. Res. Rev. 2019, 39, 831-859. [CrossRef] [PubMed]

13. Spohn, R.; Daruka, L.; Lázár, V.; Martins, A.; Vidovics, F.; Grézal, G.; Méhi, O.; Kintses, B.; Számel, M.; Jangir, P.K.; et al. Integrated evolutionary analysis reveals antimicrobial peptides with limited resistance. Nat. Commun. 2019, 10, 4538. [CrossRef]

14. Liu, Y.; Ding, S.; Shen, J.; Zhu, K. Nonribosomal antibacterial peptides that target multidrug-resistant bacteria. Nat. Prod. Rep. 2019, 36, 573-592. [CrossRef] [PubMed]

15. Lyu, Y.; Chen, T.; Shang, L.; Yang, Y.; Li, Z.; Zhu, J.; Shan, A. Design of Trp-rich dodecapeptides with broad-spectrum antimicrobial potency and membrane-disruptive mechanism. J. Med. Chem. 2019, 62, 6941-6957. [CrossRef]

16. Deslouches, B.; Phadke, S.M.; Lazarevic, V.; Cascio, M.; Islam, K.; Montelaro, R.C.; Mietzner, T.A. De novo generation of cationic antimicrobial peptides: Influence of length and tryptophan substitution on antimicrobial activity. Antimicrob. Agents Chemother. 2005, 49, 316-322. [CrossRef] [PubMed]

17. Cochran, A.G.; Skelton, N.J.; Starovasnik, M.A. Tryptophan zippers: Stable, monomeric beta -hairpins. Proc. Natl. Acad. Sci. USA 2001, 98, 5578-5583. [CrossRef] [PubMed] 
18. Wenzel, M.; Chiriac, A.I.; Otto, A.; Zweytick, D.; May, C.; Schumacher, C.; Gust, R.; Albada, H.B.; Penkova, M.; Krämer, U. Small cationic antimicrobial peptides delocalize peripheral membrane proteins. Proc. Natl. Acad. Sci. USA 2014, 111, E1409-E1418. [CrossRef]

19. Albada, H.B.; Prochnow, P.; Bobersky, S.; Langklotz, S.; Bandow, J.E.; Metzler-Nolte, N. Short antibacterial peptides with significantly reduced hemolytic activity can be identified by a systematic L-to-D exchange scan of their amino acid residues. ACS Comb. Sci. 2013, 15, 585-592. [CrossRef]

20. Albada, H.B.; Prochnow, P.; Bobersky, S.; Langklotz, S.; Schriek, P.; Bandow, J.E.; Metzler-Nolte, N. Tuning the activity of a short arg-trp antimicrobial peptide by lipidation of a C-or $N$-terminal lysine side-chain. ACS Med. Chem. Lett. 2012, 3, 980-984. [CrossRef]

21. Phambu, N.; Almarwani, B.; Garcia, A.M.; Hamza, N.S.; Muhsen, A.; Baidoo, J.E.; Sunda-Meya, A. Chain length effect on the structure and stability of antimicrobial peptides of the (RW) series. Biophys. Chem. 2017, 227, 8-13. [CrossRef] [PubMed]

22. Liu, Y.; Ding, S.; Dietrich, R.; Märtlbauer, E.; Zhu, K. A biosurfactant-inspired heptapeptide with improved specificity to kill MRSA. Angew. Chem. Int. Ed. 2017, 56, 1486-1490. [CrossRef] [PubMed]

23. Clinical and Laboratory Standards Institute. M100: Performance Standards for Antimicrobial Susceptibility Testing, 28th ed.; CLSI: Wayne, PA, USA, 2018.

24. Liu, Y.; Jia, Y.; Yang, K.; Li, R.; Xiao, X.; Wang, Z. Anti-HIV agent azidothymidine decreases Tet(X)-mediated bacterial resistance to tigecycline in Escherichia coli. Commun. Biol. 2020, 3, 162. [CrossRef] [PubMed]

25. Liu, Y.; Jia, Y.; Yang, K.; Li, R.; Xiao, X.; Zhu, K.; Wang, Z. Metformin restores tetracyclines susceptibility against multidrug resistant bacteria. Adv. Sci. 2020, 7, 1902227. [CrossRef] [PubMed]

26. Song, M.; Liu, Y.; Huang, X.; Ding, S.; Wang, Y.; Shen, J.; Zhu, K. A broad-spectrum antibiotic adjuvant reverses multidrug-resistant Gram-negative pathogens. Nat. Microbiol. 2020, 5, 1040-1050. [CrossRef] [PubMed]

27. Hamamoto, H.; Urai, M.; Ishii, K.; Yasukawa, J.; Paudel, A.; Murai, M.; Kaji, T.; Kuranaga, T.; Hamase, K.; Katsu, T.; et al. Lysocin $\mathrm{E}$ is a new antibiotic that targets menaquinone in the bacterial membrane. Nat. Chem. Biol. 2015, 11, 127-133. [CrossRef] [PubMed]

28. De, A.B.; Riool, M.; Cordfunke, R.A.; Malanovic, N.; De, L.B.; Koning, R.I.; Ravensbergen, E.; Franken, M.; Van, T.D.H.; Boekema, B.K. The antimicrobial peptide SAAP-148 combats drug-resistant bacteria and biofilms. Sci. Transl. Med. 2018, 10, eaan4044.

29. Deslouches, B.; Montelaro, R.C.; Urish, K.L.; Di, Y.P. Engineered cationic antimicrobial peptides (eCAPs) to combat multidrug-resistant bacteria. Pharmaceutics 2020, 12, 501. [CrossRef]

30. Kumar, P.; Kizhakkedathu, J.N.; Straus, S.K. Antimicrobial peptides: Diversity, mechanism of action and strategies to improve the activity and biocompatibility in vivo. Biomolecules 2018, 8, 4. [CrossRef]

31. Alvares, D.S.; Wilke, N.; Ruggiero Neto, J. Effect of N-terminal acetylation on lytic activity and lipid-packing perturbation induced in model membranes by a mastoparan-like peptide. BBA-Biomembranes 2018, 1860, 737-748. [CrossRef]

32. Bhattacharjya, S.; Straus, S.K. Design, Engineering and discovery of novel $\alpha$-helical and $\beta$-boomerang antimicrobial peptides against drug resistant bacteria. Int. J. Mol. Sci. 2020, 21, 5773. [CrossRef]

33. Fjell, C.D.; Hiss, J.A.; Hancock, R.E.; Schneider, G. Designing antimicrobial peptides: Form follows function. Nat. Rev. Drug. Discov. 2012, 11, 37-51. [CrossRef]

34. Rojas, E.R.; Billings, G.; Odermatt, P.D.; Auer, G.K.; Zhu, L.; Miguel, A.; Chang, F.; Weibel, D.B.; Theriot, J.A.; Huang, K.C. The outer membrane is an essential load-bearing element in Gram-negative bacteria. Nature 2018, 559, 617-621. [CrossRef] [PubMed]

35. Henzler-Wildman, K.A.; Martinez, G.V.; Brown, M.F.; Ramamoorthy, A. Perturbation of the hydrophobic core of lipid bilayers by the human antimicrobial peptide LL-37. Biochemistry 2004, 43, 8459-8469. [CrossRef]

36. Hallock, K.J.; Lee, D.-K.; Ramamoorthy, A. MSI-78, an analogue of the magainin antimicrobial peptides, disrupts lipid bilayer structure via positive curvature strain. Biophys. J. 2003, 84, 3052-3060. [CrossRef]

37. Malanovic, N.; Lohner, K. Gram-positive bacterial cell envelopes: The impact on the activity of antimicrobial peptides. Biochim. Biophys. Acta. 2016, 1858, 936-946. [CrossRef] [PubMed]

38. Pandidan, S.; Mechler, A. Membrane morphology effects in quartz crystal microbalance characterization of antimicrobial peptide activity. Biophys. Chem. 2020, 262, 106381. [CrossRef] 
39. Stokes, J.M.; Yang, K.; Swanson, K.; Jin, W.; Cubillos-Ruiz, A.; Donghia, N.M.; MacNair, C.R.; French, S.; Carfrae, L.A.; Bloom-Ackerman, Z.; et al. A deep learning approach to antibiotic discovery. Cell 2020, 180, 688-702.e13. [CrossRef]

40. Liu, Y.; Li, R.; Xiao, X.; Wang, Z. Bacterial metabolism-inspired molecules to modulate antibiotic efficacy. J. Antimicrob. Chemother. 2019, 74, 3409-3417. [CrossRef]

(C) 2020 by the authors. Licensee MDPI, Basel, Switzerland. This article is an open access article distributed under the terms and conditions of the Creative Commons Attribution (CC BY) license (http://creativecommons.org/licenses/by/4.0/). 